\title{
Nepoznati obzori poznatih prostora
}

Kao dio strategije jačanja značaja i vidljivosti Instituta za društvena istraživanja u Zagrebu, a kroz poticanje rasprava o novim znanstvenim spoznajama, časopis Sociologija i prostor raspisao je natječaj „Najbolji studentski rad u 2021. godini“. Naime, Sociologija i prostor (prije Sociologija sela) već je dugi niz godina vodeći domaći i regionalni časopis za istraživanje prostora iz perspektive urbane i ruralne sociologije te srodnih znanstvenih disciplina. Još od 1963. godine uredništvu časopisa cilj je promoviranje društvenih tema ruralne ili urbane problematike, koje danas, zahvaljujući novim generacijama, imaju nove obrise.

Generacije urednika i uredništava našega časopisa trudile su se svojom uredničkom politikom motivirati potencijalne suradnike na istraživanje društvenih promjena koje su se događale u ruralnom i urbanom prostoru u Hrvatskoj i u regiji, a ponekad i šire. Pažljivo osluškujući znakove vremena uredništva su usmjeravala časopis ka održanju kontinuiteta i interdisciplinarnosti, ali i nužnim promjenama koje su se odnosile na niz društvenih i znanstvenih aspekata koji su određivali politiku časopisa. $\mathrm{Na}$ te su promjene dobrim dijelom utjecali i potencijalni suradnici koji su slali tekstove na objavu. Fokus se mijenjao - najprije sa sela na grad, pa na prostor općenito, pa na još širi obuhvat tema i, zadnjih godina, na povratak temama prostora shvaćenog u najširem smislu. Uz velike teme, autori su se sve više fokusirali i na teme skrivene u nišama društvene i znanstvene zbilje, a takve su upravo teme autora koji su se javili na ovaj natječaj: Nepoznati obzori poznatih prostora.

Cilj ovog natječaja za najbolji studentski rad bio je potaknuti dijalog o prostornoj problematici objavljivanjem tekstova mlade generacije - samostalno ili u koautorstvu s kolegicama i kolegama, mentoricama ili mentorima. U definiranju kriterija natječaja uredništvo je bilo otvoreno za različite perspektive koje se bave prostorom i okolišem, podjednako uvažavajući kvalitativna i kvantitativna istraživanja te studije slučaja, osvrte na najbolje prakse i slično. Stoga smo poslali međunarodni poziv studentima i studenticama domaćih i stranih sveučilišta na svim razinama diplomskih i poslijediplomskih studija sociologije, antropologije, politologije, geografije, arhitekture i srodnih znanosti da prijave svoje tekstove o različitim aspektima suvremene prostorne, a time i šire društvene, kulturne, ekonomske, obrazovne, demografske i političke problematike.

Natječaj je objavljen 19. siječnja 2021. godine, a jedini formalni kriterij bio je da prvi autor/ica rada nema obranjen doktorat u 2021. godini. Rok za predaju radova bio je 1 . listopada 2021. godine, a pristiglo je ukupno pet radova koji su zadovoljili kriterije za objavljivanje, naime prošli su dvostruko slijepu recenziju (engl. double-blind review).

Dva pristigla rada objedinila su dvije važne teme u društvenim znanostima - probleme mladih ljudi koji su odlučili živjeti u ruralnim prostorima, dok treći rad donosi ur- 
banu problematiku, tj. analizu novog „nemjesta“ - trgovačkog centra Arena u Laništu u Zagrebu. Četvrti rad problematizira svakodnevni život stanovništva unutar gentrificirane stare jezgre Dubrovnika, a peti rad opisuje subjektivne doživljaje Karlovčana vezanih za staru Kuglanu kao „mjesta“ i restorana brze hrane McDonald's kao nemjesta. Mladi budući znanstvenici koji vide svijet kroz generacijske naočale poigrali su se $s$ društvenim činjenicama svijeta koji kao da se okreće naglavačke. Originalnošću tema i korektnim znanstvenim pristupom uklopili su se u tematski i istraživački kontekst ostalih radova o aktualnim prostornim temama, svjedočeći zajedno raznolikost, nedostatke, ali i mogućnosti života u hrvatskom prostoru, kao i znanstvenu kompetentnost.

Ovaj broj donosi četiri istraživanja koja zaokružuju četiri znanstveno-istraživačke teme Instituta za društvena istraživanja u Zagrebu. Prvi rad, pod nazivom Obnova zagrebačkog Donjeg grada nakon potresa iz perspektive stanara, napisale su Anđelina Svirčić Gotovac, Jelena Zlatar Gamberožić i Mirjana Adamović. Tekst donosi subjektivne doživljaje stanara, njihove interpretacije problema te nadanja i očekivanja od različitih političkih aktera u sanaciji nastalih šteta nakon razornog potresa. Autorice su provele istraživanje kvalitativnom metodom polustrukturiranih intervjua na uzorku vlasnika stanova i predstavnika suvlasnika u zagrebačkom Donjem gradu. Rezultati pokazuju kako sanacija zgrada teče sporo te da proces obnove nije u skladu s očekivanjima sugovornika, odnosno da će se u procesu obnove stanari, unatoč subvencijama i donesenom Zakonu o obnovi te mogućnostima sufinanciranja, trebati značajnije osloniti na vlastitu podršku, financijsku i organizacijsku.

Rad Jelene Puđak pod naslovom How Environmentalists Deal with (Yet Another) Global Crisis: Resilience, Vulnerability, and Intersecting Crises s Instituta društvenih znanosti „Ivo Pilar“ dio je istraživanja u sklopu projekta HRZZ „Otpornost hrvatskog društva uslijed COVID-19 pandemije (SOCRES)”. Autorica razmatra činjenice koje ukazuju na to kako u procesu izgradnje otpornosti društva tijekom pandemije civilni sektor ima važnu, ali zapostavljenu društvenu ulogu. Puđak naglašava kako ključnu podršku u prevladavanju krize mora zauzeti pokret za okoliš, kao jedan od najuspješnijih društvenih pokreta koji spaja pitanja zaštite okoliša s konceptima socijalne pravde i ekonomskog razvoja. Rezultati ovog istraživanja upućuju na zaključak da intersekcijske krize koje proizlaze iz složenog odnosa čovjeka i prirode postavljaju izazov traženja i pronalaženja učinkovitog okvira u definiranju problema unutar pokreta te ponovno uspostavljanje korektivne uloge u društvu.

Problem svjetlosnog onečišćenja analiziraju Hrvoje Grofelnik sa Sveučilišta u Rijeci te Marko Miočić i Tomislav Golubić, profesori zagrebačke odnosno riječke prirodoslovne gimnazije. Rad Osjetljivost gimnazijalaca na svjetlosno onečišćenje u Republici Hrvatskoj rezultat je anketnog istraživanja na nacionalnoj razini po pitanju poznavanja problematike, svjesnosti i stavova učenika gimnazijskih programa prema problemu 
svjetlosnog onečišćenja. Istraživanje nije usmjereno ka usporedbi razine svjetlosnog onečišćenja u prostoru, već na dublje poznavanje problematike. Izdvojeni su subjektivni stavovi i percepcije gimnazijalaca prema utjecaju svjetlosnog onečišćenja na okoliš. Rezultati pokazuju homogenost na nacionalnoj razini u poznavanju problematike, svjesnosti i stavovima o svjetlosnom onečišćenju te relativno visoku svijest mladih ljudi, gimnazijalaca, o tom problemu.

Rezultate istraživanja o vršnjačkom pritisku analiziraju Mirjana Radetić Pajić i Sandra Kadum sa Sveučilišta u Puli i Jasna Kudek Mirošević sa Sveučilišta u Zagrebu u radu Razlike u podložnosti vršnjačkom pritisku studenata u različitim mjestima studiranja. Autorice naglašavaju da ključnu ulogu u razdoblju adolescencije zauzimaju vršnjački odnosi. Posredno ili neposredno, ti odnosi imaju za posljedicu potrebu za činjenjem onoga što zahtijevaju vršnjaci, a što je vidljivo po odlukama koje adolescenti donose, kao i po načinu na koji se ponašaju. Cilj ovoga rada utvrditi je jesu li i u kojem obimu studenti podložni vršnjačkom pritisku i, ukoliko jesu, koja su to specifična obilježja razlika u podložnosti tom pritisku između studenata Fakulteta za odgojne i obrazovne znanosti Sveučilišta Jurja Dobrile u Puli i Učiteljskog fakulteta Sveučilišta u Zagrebu, Odsjeka u Petrinji.

Prvi rad mladih znanstvenika/ca, pod naslovom Iskustva mladih obiteljskih poljoprivrednih gospodarstvenika (OPG-ovaca) u Bjelovarsko-bilogorskoj i Požeškoslavonskoj županiji, napisala je Helena Pupak s Filozofskog fakulteta Sveučilišta u Zagrebu u koautorstvu s mentoricom doc. dr. sc. Tijanom Trako Poljak s Odsjeka za sociologiju. Autorice u radu analiziraju iskustvo života i rada mladih obiteljskih poljoprivrednih gospodarstvenika (OPG-ovaca) u dvije hrvatske županije, opisujući izazove života u hrvatskim ruralnim područjima te posljedično dobre i loše strane rada „na zemlji“ ili života „od zemlje“. Operacionalizacijom odabranih objektivnih i subjektivnih domena kvalitete života provedeno je iznimno zanimljivo kvalitativno istraživanje koje donosi kritiku, ali i smjernice zamišljenog razvoja seoskih zajednica. Autorice ističu da „današnje stanje ruralnih područja i poljoprivrede u Hrvatskoj nužno je preokrenuti, a sami stanovnici tih područja daju vrijedne podatke o svojoj percepciji smjera i sadržaja tih promjena." Ističe se razmatranje razvoja mreže naselja, što omogućuje zadovoljenje osnovnih životnih potreba stanovnika, koje je zbog infrastrukturne neopremljenosti teško ispuniti. Autorice ističu temu značaja zadrugarstva kao potencijalnog rješenja koje bi poljoprivrednicima omogućilo zajedničko obavljanje poljoprivredne djelatnosti osiguravajući proizvodnju, poljoprivredno zemljište i resurse, ali i nadvladavanje mnogih problema i poteškoća.

Drugi rad mladih znanstvenika Za ili protiv života na selu? Stavovi visokoobrazovanih mladih ljudi o životu u hrvatskim ruralnim područjima napisali su Tihana Kuzmić i Bruno Šimac s Filozofskog fakulteta Sveučilišta u Zagrebu u koautorstvu s mentoricom doc. dr. sc. Tijanom Trako Poljak s Odsjeka za sociologiju. Autori u radu 
obrađuju aktualnu temu održivosti tj. vitaliteta hrvatskih ruralnih područja, kako u demografskom tako i u ekonomskom, socijalnom, kulturnom i političkom smislu. Smanjenje broja mladih u ruralnim prostorima očituje se u mnogim aspektima, primjerice u deagrarizaciji, odnosno sveukupnoj deruralizaciji i kontinuiranom propadanju tih područja kao mjesta življenja i rada. S obzirom na to da mlado stanovništvo uglavnom odlazi zbog daljnjeg obrazovanja ili zaposlenja, prilike za što ima naročito malo za one s višim obrazovanjem, cilj je ovog rada prikazati koji čimbenici privlače i/ili odbijaju mlade visokoobrazovane ljude da svoju budućnost vežu za ruralna područja Republike Hrvatske. Rad donosi zanimljive rezultate koji govore kako visokoobrazovani mladi ključnim smatraju poboljšanje komunalne i prometne infrastrukture, ali i mogućnost zaposlenja u struci. Vezano uz rad u poljoprivredi, smatraju da bi im novčani poticaji, posebice urbanim mladima koji nemaju obiteljsko zemljište ili postojeću infrastrukturu, olakšali početak bavljenja poljoprivredom.

Geografija nemjesta; Analiza Arena Centra u Zagrebu (makrorazina) donosi novu perspektivu u „stari“ istraživački prostor mladog znanstvenika Karla Maka, zaposlenog u gimnaziji Antuna Gustava Matoša u Samoboru i izv. prof. dr. sc. Martine Jakovčić s Prirodoslovno-matematički fakulteta Sveučilišta u Zagrebu, s Geografskog odsjeka. Na temelju Augéovog koncepta nemjesta autori su postavili interpretativni model analize trgovačkog centra (mikrorazina) te urbanog prostora koji se oko njega stvara (makrorazina). U svrhu funkcionalnog povezivanja tih dviju razina primijenili su De Certeauov koncept potrošačke proizvodnje, prema kojem ljudi nisu tek pasivni konzumenti prostora, već nepredvidljivim prostornim ponašanjem sudjeluju u kreaciji nestabilnih prostornih veza i odnosa. Ovaj rad donosi rezultate istraživanja na makrorazini, a temelji se na markerima tranzitnosti koje posjetitelji Arena Centra ostavljaju u prostoru. Autori su proveli terensko istraživanje, kartiranje, fotografiranje te metodu promatranja. U radu su dokazali da Arena Centar kao najveći trgovački centar tendira okolni prostor transformirati u nemjesto, koje ima sklonost agregiranja, o čemu svjedoče raznorodne prostorne oznake tranzitnosti te dinamične morfološke, funkcionalne i demografske promjene.

Rad (Pre)živjeti unutar dubrovačke stare jezgre - priča o Gradu iz perspektive lokalnog stanovništva Nike Đuho, Maje Golubić i Karla Tukše, troje studenata sociologije na Odjela za sociologiju Katoličkog sveučilišta, prikazuje simboličko značenje i iskustvo života unutar dubrovačke stare jezgre. Koristeći se metodom narativnog urbanizma, koja uključuje prikupljanje podataka kroz razgovor i šetnju lokalitetima unutar jezgre, glavni nalazi ukazuju na to kako su dostupnost različitih sadržaja te ambijentalna posebnost glavni aspekti privlačnosti za život unutar stare jezgre, koja paradoksalno tada stanovnike prekrasnog grada pretvara u žrtve njegove povijesti i kulture kroz kontinuiranu uzurpaciju njihove svakodnevne rutine. Međutim, detaljnija analiza pokazat će da identitet lokalnog stanovništva nije statičan te da se ostvaruje kroz dvije naizgled proturječne, a ipak komplementarne kategorije - kategoriju stanovnika i kategoriju domaćina turistima. 
Subjektivno iskustvo mjesta $i$ nemjesta na primjeru istraživanja Kuglane i McDonald'sa u Karlovcu napisale su studentica Martina Čoko i doc. dr. sc. Ivana Brstilo Lovrić. Istraživanjem se utvrdilo da je Kuglana u Domu HV Zrinski u Karlovcu korespondentna ideji mjesta, dok McDonald's odražava karakteristike nemjesta. Sudionici su opisali Kuglanu kao svoje mjesto od osobnoga i zajedničkoga značenja, $s$ kojim su se emotivno povezali na razini uspomena, aktivnosti i uloga. Kuglana je kao „Kafić Uzdravlje“, dom gdje se osjećaju pripadno, sigurno i opušteno, odnosno kao insajderi, a restoran brze hrane - McDonald's je pak opisan kroz odsutnost dubljih značenja i uspomena te minimalne socijalne odnose, potvrđujući nemjesto kao neosobnu kategoriju u kojoj sudionici funkcioniraju kao autsajderi.

Za kraj, važno je napomenuti da ćemo rezultat natječaja, koji je u međuvremenu dobio naziv Nepoznati obzori poznatih prostora, kao i osvrt uredništva na kriterije za dodjelu nagrade, objaviti u sljedećem broju našeg časopisa.

Ankica Marinović

Glavna i odgovorna urednica

Lana Peternel

Izvršna urednica 